\title{
Genotypic and phenotypic differences between Baltic and North Sea populations of Mytilus edulis evaluated through reciprocal transplantations. II. Genetic variation
}

\author{
Kerstin Johannesson ${ }^{1}$, Nils Kautsky ${ }^{2}$, Michael Tedengren ${ }^{2}$ \\ ${ }^{1}$ Tjärnö Marine Biological Laboratory, Pl. 2781, S-452 00 Strömstad, Sweden \\ ${ }^{2}$ Askö Laboratory, Institute of Marine Ecology and Department of Zoology, University of Stockholm, S-106 91 Stockholm, \\ Sweden
}

\begin{abstract}
There are large differences in allozyme frequencies between Baltic and North Sea populations of Mytilus edulis. These differences have recently been ascribed to the presence of 2 species, viz. $M$. edulis L. in the North Sea and $M$. trossulus Gould in the Baltic. Our study supports the earlier findings of an extensive differentiation between North Sea and Baltic mussels. However, in reciprocal transplantations of mussels between a North Sea (20 to $30 \%$ S) and a Baltic (6 to $7 \%$ S) site, $96 \%$ of the North Sea mussels transferred to the Baltic site died immediately. Baltic mussels transferred to the North Sea site survived the first year but $99 \%$ suddenly died after 16 mo. The deaths altered the allele frequencies of the transplanted populations drastically at the 2 loci Pgm (phosphoglucomutase) and Pgi (phosphoglucose isomerase). The surviving Pgi genotypes were very similar to those of mussels native to each site, and this was true also for surviving Pgm genotypes of Baltic mussels transplanted to the North Sea. The genotype distribution of the surviving mussels also suggests that Pgi and Pgm are in linkage-disequilibrium. Allele frequencies at the Ap (aminopeptidase) locus did not differ between Baltic and North Sea populations, possibly as a result of a gene flow between Baltic and North Sea mussels. Rare alleles of 'wrong' types being present in both North Sea and Baltic populations at the loci Lap (leucine aminopeptidase, also called Lap-2), Pgm and Pgi supports the lack of a reproductive barrier. This study shows that substantial genetic differentiation may be maintained by selection, and we suggest that Baltic and North Sea mussels might well be of the same evolutionary lineage
\end{abstract}

\section{INTRODUCTION}

Mytilus edulis has a high potential for dispersal during a planktonic larval stage of several weeks. It is therefore not surprising that the species in some areas seems to be genetically rather homogeneous, as, for example, in the North Sea (Fevolden \& Garner 1986), in the Baltic (Bulnheim \& Gosling 1988), and around the parts of the British and Irish coasts where Mytilus galloprovincialis Lmk is absent (Skibinski et al. 1983). More surprising, perhaps, is the finding of a substantial amount of variation in some allozyme loci over relatively short distances, on the order kilometres or less (Koehn et al. 1976, Theisen 1978, Gartner-Kepkay et al. 1983, Koehn et al. 1984).

Reproductive isolation between populations acts as a barrier to genetic exchange and will cause genetic differentiation over time as a result of stochastic processes in neutral loci. Genetic differentiation may alternatively be a consequence of selection at assayed loci, or at loci which are coupled to the selected loci. It is difficult to distinguish between genetic drift and selection in a descriptive study if the 2 genetically distinct groups are found allo- or parapatrically, because selection may differ between the 2 environments and genetic differences may arise despite a substantial gene flow (but see Hilbish \& Koehn 1985a). The possibility of differential selection may, however, be examined through reciprocal transplants of non-sympatric populations.

In a series of descriptive and experimental sludies of Mytilus edulis, Koehn, Hilbish and co-workers have 
worked out the molecular mechanism of selection acting on the highly polymorphic Lap locus which shows a clinal variation along a salinity gradient in Long Island Sound (Koehn 1978, Koehn et al. 1980, Hilbish et al. 1982, Hilbish \& Koehn 1985b). The genetic variation is extensive; the $L a p^{94}$ allele, for example, changes its frequency from 0.55 to 0.12 over a distance of $30 \mathrm{~km}$ (Koehn et al. 1976) and a salinity change of $3.5 \%$. In the Baltic proper the surface salinity is 6 to $8 \%$, while in the Kattegat part of the North Sea it is about $20 \%$ and sharp salinity gradients are built up in the Oresund and the Belts. Theisen (1978) found gradual shifts in allele frequencies of the 3 loci Pgi, Pgm and Lap over these salinity gradients. Bulnheim \& Gosling (1988) confirmed Theisen's findings of a rather homogeneous situation in the Baltic and in the North Sea and steep genetic clines in between. Theisen (1978) transplanted mussels from a site of 8 to $10 \% \mathrm{~S}$ to a site of 14 to $17 \% \mathrm{~S}$ and found that different genotypes of the transplanted mussels had different survival rates, indicating selection at the 2 loci Pgi and Pgm, and to a less extent at Lap.

Bulnheim \& Gosling (1988) found substantial differences at the loci Pgm, Pgi, Lap, Odh, and Est-D (= Est). No differences were, however, found at the polymorphic Ap locus. Varvio et al. (1988) similarly revealed large differences between North Sea and Baltic mussels at Pgm, Gpi $(=P g i), L a p$ and $M p i$, but not at the polymorphic loci Odh, Ap and Aap (= Lap-1). At Pgm and $P g i$ the Baltic mussels were more similar to mussels from certain areas of Canada (Group III of Koehn et al. 1984) than to North Sea mussels, while at Ap the Baltic

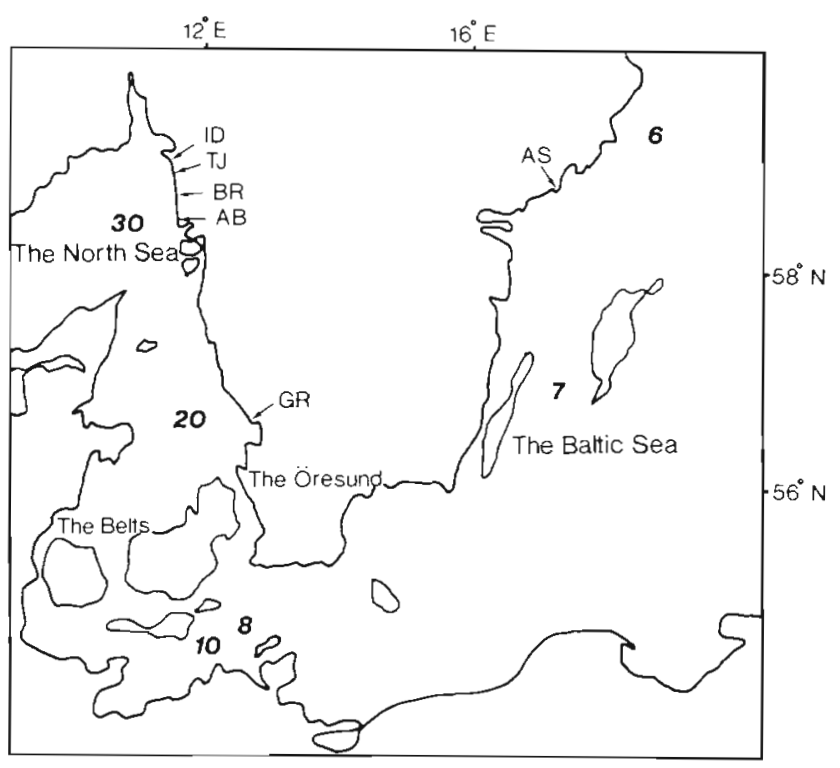

Fig. 1. Locations of sampled populations of Mytilus edulis along the Swedish North Sea coast and in the Baltic Sea. Surface salinities are indicated in bold italics mussels were most closely related to the North Sea population, and at Lap the Baltic, North Sea and Group III mussels were all different from each other. In both studies the conclusion was that the Baltic mussels represent an evolutionary lineage separate from the North Sea mussels. McDonald \& Koehn (1988) have since revived the species name Mytilus trossulus for Baltic mussels, and for mussels from part of the Atlantic coast of Canada (intermingled with $M$. edulis), the Pacific coast of North America from northern California (where it hybridizes with $M$. galloprovincialis) to Alaska, and the Pacific coast of the Soviet Union.

The transplant experiment by Theisen (1978) suggests, however, the possibility that the allozymic differences found between Baltic and North Sea populations are due to differential selection over the steep salinity gradient between the 2 regions. In this study we examine this possibility further by analyzing geographical and temporal variation along the Swedish west coast (North Sea sites), and by making reciprocal transplants of mussels from a site well within the Baltic proper and a site on the Swedish North Sea coast.

This study is accompanied by a study, which deals with growth and morphology (Kautsky et al. 1990), and another which deals with physiology (Tedengren et al. 1990) of the mussels transplanted between the Baltic and the North Sea sites.

\section{MATERIAL AND METHODS}

Populations studied. Geographical and temporal allozyme variation were assayed in up to 4 different year classes of mussels from 5 North Sea and 1 Baltic site (Fig. 1; Table 1). Most populations were from small commercial farms of rope-cultured mussels. These populations are recruited from the natural pool of pelagic larvae. The advantage of sampling cultured mussels is that their ages are known. The salinity of the Baltic site is 6 to $7 \%$, while salinities at the North Sea sites are 10 to $30 \%$, with more pronounced fluctuations and lower average values in the southern parts and in estuaries

A rope with about 600 small mussels settled in June 1984 was transferred from a North Sea site $(20$ to $30 \%$ S) to the Baltic site at the end of September 1984. Large numbers (ten thousands) of Baltic mussels of different year classes attached to ropes were transplanted to the North Sea site on 4 occasions during the period 1984 to 1986. The transferred mussels were stepwise acclimatized to the ambient salinity of the new site over about a week in the laboratory (for details see Kautsky et al. 1990). Thereafter they were transferred to the sea (still on their ropes) and placed at a depth of about $9 \mathrm{~m}$ where settling rate of native mussel larvae generally is 
Table 1. Description of sampled localities. The benthic mussels were asigned an approximate age based on the length distribution of the samples and the time of sampling

\begin{tabular}{|c|c|c|c|c|c|c|}
\hline Sample & Locality & & Year class & Substratum & Depth. & Salinity \\
\hline \multicolumn{7}{|c|}{ North Sea populations: } \\
\hline $\begin{array}{l}\text { ID 83, }-87 \\
\text { TJ82, }-84,-85,-87\end{array}$ & $\begin{array}{l}\text { Idefjorden } \\
\text { Tjärnö }\end{array}$ & $\begin{array}{l}59^{\circ} 6^{\prime} \mathrm{N}, 11^{\circ} 17^{\prime} \mathrm{E} \\
58^{\circ} 53^{\prime} \mathrm{N}, 11^{\circ} 9^{\prime} \mathrm{E}\end{array}$ & $\begin{array}{l}1983,87 \\
1982,84,85,87\end{array}$ & $\begin{array}{l}\text { Benthic } \\
\text { Rope }\end{array}$ & $\begin{array}{l}8-10 \mathrm{~m} \\
0-9 \mathrm{~m}\end{array}$ & $\begin{array}{l}5-25 \% \\
19-30 \%{ }^{a}\end{array}$ \\
\hline \multicolumn{7}{|c|}{ TJ84 (transferred sample from Tjärnö; see Table 4) } \\
\hline $\begin{array}{l}\text { BR82, }-83 \\
\text { AB82, }-83 \\
\text { GR82 }\end{array}$ & $\begin{array}{l}\text { Brattö } \\
\text { Äbyfjorden } \\
\text { Grötvik }\end{array}$ & $\begin{array}{l}58^{\circ} 34^{\prime} N, 11^{\circ} 16^{\prime} E \\
58^{\circ} 24^{\prime} \text { N, } 11^{\circ} 24^{\prime} E \\
56^{\circ} 38^{\prime} \text { N. } 12^{\circ} 49^{\prime} E\end{array}$ & $\begin{array}{l}1982,83 \\
1982,83 \\
1982\end{array}$ & $\begin{array}{l}\text { Rope } \\
\text { Rope } \\
\text { Benthic }\end{array}$ & $\begin{array}{l}0-9 \mathrm{~m} \\
0-9 \mathrm{~m} \\
0.5 \mathrm{~m}\end{array}$ & $\begin{array}{r}17-29 \% \%^{a} \\
16-27 \%{ }^{a} \\
9-19 \%{ }^{b}\end{array}$ \\
\hline \multicolumn{7}{|l|}{ Baltic populations: } \\
\hline AS83 & Askö & $58^{\circ} 49^{\prime} \mathrm{N}, 17^{\circ} 38^{\prime} \mathrm{E}$ & 1983 & Rope & $9 \mathrm{~m}$ & $5-7 \% o^{b}$ \\
\hline $\begin{array}{l}\text { AS83 },-84^{\circ},-85^{\circ} \\
{ }^{a} \text { From Rödström \& } \\
\text { brom Norman (19 }\end{array}$ & $\begin{array}{l}-86^{\circ} \text { (transfer } \\
\text { Loo (pers. co } \\
77 \text { ) }\end{array}$ & mples from Askö; see & & & & \\
\hline
\end{tabular}

very low (Romare et al. 1982). The ropes were inspected weekly from June to September by SCUBAdiving and all newly metamorphosed mussels (which were much smaller than the transferred ones) were removed. Settling rate was very low at this depth as judged from settling on empty parts of the rope.

Genetic analysis. Twelve loci were assayed by horizontal starch gel $(12.5 \%)$ electrophoresis. Two buffer systems were used: (I) continuous tris-citric acid, $\mathrm{pH}$ 8.0 (electrode buffer: $0.25 \mathrm{M}$ tris, $0.057 \mathrm{M}$ citric acid; gel buffer: 25:1 dilution of electrode buffer); (II) discontinuous tris-citrate-borate, $\mathrm{pH} 8.6$ (electrode buffer: $0.3 \mathrm{M}$ boric acid, $0.1 \mathrm{M}$ sodium hydroxide; gel buffer: $0.066 \mathrm{M}$ tris, $0.007 \mathrm{M}$ citric acid, mixed 9:1 with electrode buffer). Parts of the hepatopancreas were homogenized in $0.1 \mathrm{M}$ tris- $\mathrm{HCl}, \mathrm{pH} 8.0$ and absorbed onto filter paper for subsequent electrophoresis. Enzyme stains were modified after Shaw \& Prasad (1970) and Harris \& Hopkinson (1976). Esterases were stained using 1-naphthyl acetate and fast blue BB. Three (isocitrate dehydrogenase, Idh, EC code 1.1.1.42; mannose phosphate isomerase, Mpi. 5.3.1.8; and esterase, Est, 3.1.1.1) gave poor resolutions and were not included in the evaluation of data. Five loci revealed none or very little genetic variation (malate dehydrogenase, $M d h, 1.1 .1 .37$; xanthine dehydrogenase, $X d h, \quad 1.2 .3 .2 ; \quad \alpha$-glycerophosphate dehydrogenase, a-Gpdh, 1.1.1.8; superoxide dismutase, Sod, 1.15.1.1; and aspartate aminotransferase, Aat, 2.6.1.1), while the remaining 4 (leucine aminopeptidase, Lap, 3.4.11.-i aminopeptidase, Ap, 3.4.---; phosphoglucose isomerase, $P g i, 5.3 .1 .9 ;$ and phosphoglucomutase, Pgm, 2.7.5.1) were polymorphic and stained well in most runs. Pgi, Pgm and Lap have been shown to have Mendelian inheritance (Hvilsom \& Theisen 1984).

\section{RESULTS}

\section{Geographic and temporal genetic variation}

The North Sea and Baltic mussels were very different at the loci Pgi, Pgm and Lap, while there were only minor differences at $A p$ (Fig. 2). Baltic mussels had a predominance of slow-moving allozymes at Pgi and fast-moving allozymes at Pgm relative to the North Sea mussels. At Lap, a fast-moving allozyme was typical of the Baltic population but rare in the North Sea populations, while an allozyme of intermediate mobility was rare in the Baltic and fairly common among the North Sea mussels (Table 2).

The North Sea populations were somewhat different to each other as revealed by a genic contingency chisquare test (Workman \& Niswander 1970); at $P g i \chi^{2}=$ $124(\mathrm{df}=40, \mathrm{p}<0.005)$, at Pgm $\chi^{2}=118.9(\mathrm{df}=50, \mathrm{p}$ $<0.005)$, at $A p \chi^{2}=66.4(\mathrm{df}=35, \mathrm{p}<0.005)$, and at Lap $\chi^{2}=41.8(\mathrm{df}=24, \mathrm{p}<0.025)$. A cluster analysis (UPGMA) of Nei's pairwise genetic identities ( $I_{i}$ Nei 1972), indicated that the population ID83, and to a minor extent ID87 and GR82, contributed the most to this heterogeneity in Pgi. At Pgm the population ID87. and at Lap. ID83, were most different from the other populations. At Ap there was no particular population which deviated from the main cluster. ID is a polluted estuarine site with pronounced fluctuations in salinity and GR is the southernmost North Sea site with the lowest salinity of the North Sea sites (Table 1). It was noted that the ID87 sample included a number of individuals with abnormal shell shapes.

There were small but significant variations between year classes at some sites (Table 3), at TJ (for $P g I$ ), at $A B$ (for Pgi and Pgm) and at ID (for Pgi and Pgm). The polluted estuarine site ID had the greatest between- 


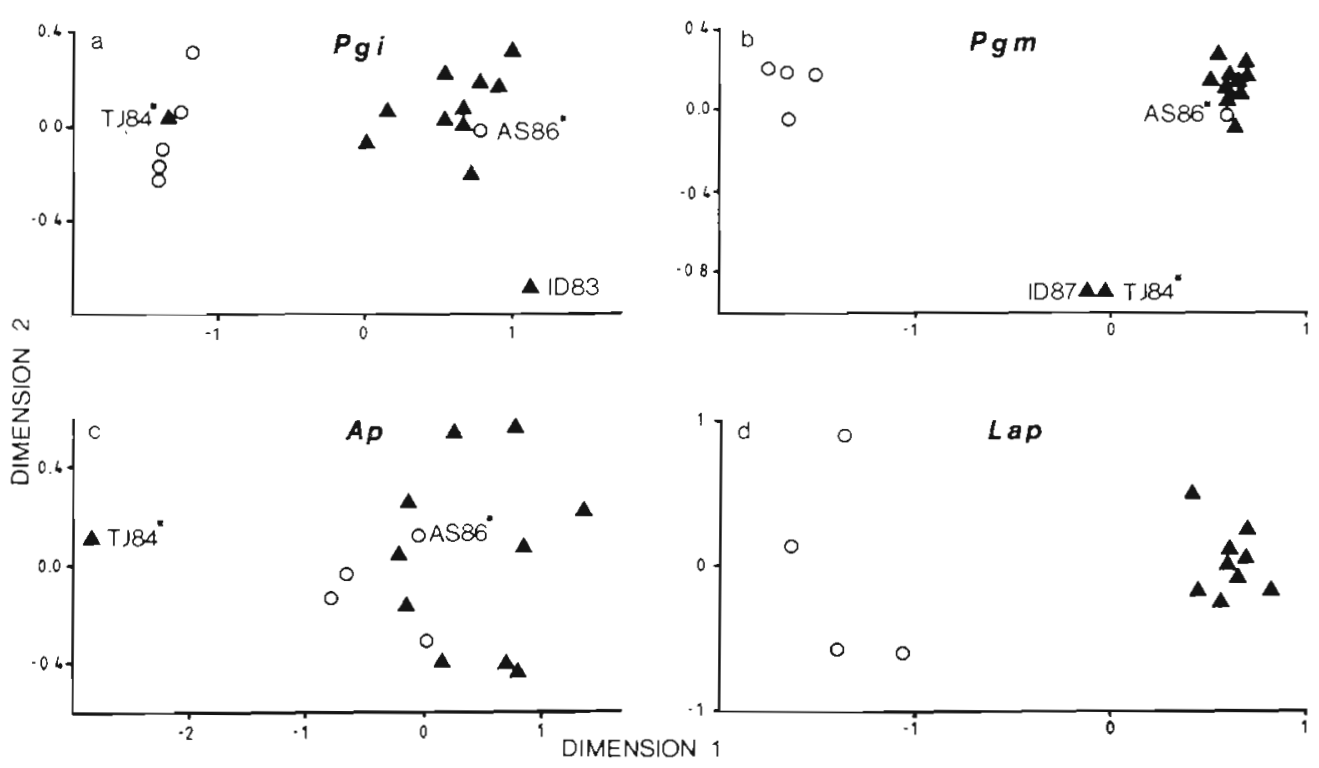

Fig. 2. Multi-dimensional scaling of genetic distance (Nei's D) matrices based on allele frequencies at each of 4 loci (a to d). ( $\mathbf{A}$ ) North Sea; (O) Baltic populations. TJ84 $4^{\circ}$ was transferred to AS in the Baltic and AS86 ${ }^{*}$ to TJ in the North Sea. Both suffered from very high mortality rates. ID83 and ID87 are from a polluted estuary with pronounced salinity fluctuations

year variation. No population revealed deviations from Hardy-Weinberg expected proportions of genotypes, but this does not rule out the possibility of non-random mating as large samples have to be analysed to test this possibility (Fairbairn \& Roff 1981).

\section{Survival and selection of transplanted mussels}

The 4 samples of transferred Baltic mussels between 2-and 14-mo-old grew for different periods in the high salinity of the North Sea prior to genetic analysis (Table 4 ). Three of the samples (AS83 ${ }^{\circ}, \mathrm{AS} 84^{\circ}$ and AS85') which grew 1, 2 and 8 mo, respectively, had survival rates similar to those of native populations. The mussels of AS86 ' likewise survived well for the first $16 \mathrm{mo}$, but in late September 1987 most individuals suddenly died (see Tedengren et al. 1990). Only about 200 of the ca 40000 transferred mussels survived and these were sampled for genetic analysis in August 1988.

The 3 low mortality samples (AS83*, AS84 *, AS85*) had allele frequency distributions similar to the untransferred Baltic population (AS83) at Pgi, Pgm, Ap and Lap. The sample (AS86 $6^{\circ}$ ) with a mortality rate of $99.5 \%$ became similar to the North Sea populations at Pgi and Pgm (Table 2; Fig. 2a, b), while at Ap there had been no selective mortality (Table 2; Fig. $2 c$ ). Unfortunately, Lap did not stain accurately in the analysis of this sample.

A few of the alleles of Pgi and Pgm found at high frequencies in the selected population (AS86 ${ }^{\circ}$ ) were not found in the unselected Baltic samples. However, the large number of transferred mussels (ca 40000), the extremely high mortality rate, and the relatively small sample sizes of the unselected populations (19 to 52) may account for this. The genotype distribution of the selected population indicates, however, that Pgi is likely to be in linkage disequilibrium with $\mathrm{Pgm}$, as the surviving population have high frequencies of rare alleles at both $P g i$ and $P g m$. That is, a relatively high number of the surviving mussels carried both allele 2 of Pgi and allele 4 of Pgm.

One of the transplanted Baltic samples (AS85 ) deviated from Hardy-Weinberg expected genotype frequencies with an excess of $\mathrm{Pgm}^{44}$ homozygotes $(\mathrm{G}=$ 27.8, $\mathrm{df}=15, \mathrm{p}<0.025$ ). The reason for this is not obvious. The possibility of a contamination with North Sea mussels is rejected as then an excess of $P_{g i}{ }^{22}$ homozygotes would also have been present.

The North Sea mussels transferred to the Baltic site (TJ84") suffered from a high immediate mortality, which is in contrast to the high survival rate of the transferred Baltic mussels during the first year. Of the 600 transferred North Sea mussels of 1 to $40 \mathrm{~mm}$ in size (mean $21 \mathrm{~mm}$ ), only 22 of the smallest $(2.0 \pm 0.2 \mathrm{~mm}$ in size) survived during the week of stepwise adaptation in the laboratory to a salinity of $6 \%$. The survivors were put out for $20 \mathrm{mo}$, and during this period no further mortality was observed and the mussels grew to an average size of $22.0 \pm 1.9 \mathrm{~mm}$.

The initial mortality in TJ84 ${ }^{*}$ was coupled to a strong differential selection of genotypes at, particularly, $P g i$, at $P g m$ and, to a minor extent, at Ap. At Pgi the resulting allelic distribution was very similar to that of 


\begin{tabular}{|c|c|c|c|c|}
\hline $\begin{array}{l}\infty \\
\infty \\
0 \\
\&\end{array}$ & 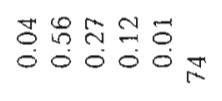 & 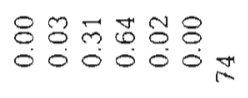 & $\begin{array}{lllll}1 & 1 & 1 & 1 & 1\end{array}$ & 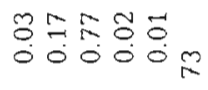 \\
\hline $\begin{array}{l}\dot{i} \\
\infty \\
i \\
i\end{array}$ & 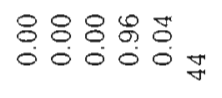 & 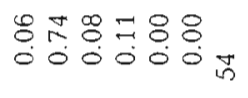 & 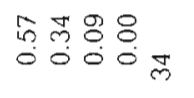 & 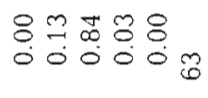 \\
\hline $\begin{array}{l}\dot{\dot{D}} \\
\dot{0} \\
\dot{\alpha}\end{array}$ & 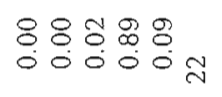 & 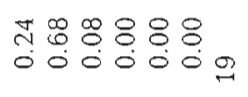 & 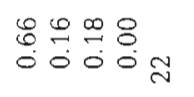 & 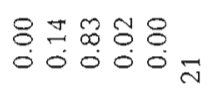 \\
\hline $\begin{array}{l}\dot{\hat{\infty}} \\
\dot{\infty}\end{array}$ & 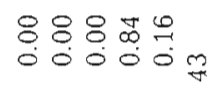 & 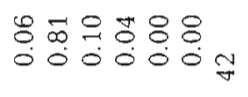 & 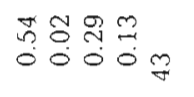 & $\begin{array}{llllll}1 & 1 & 1 & 1 & 1 & 1\end{array}$ \\
\hline 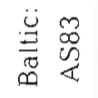 & $\begin{array}{l}8: 8 \% 0 \\
00000 \\
000 \\
0\end{array}$ & 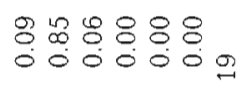 & $\begin{array}{l}\overrightarrow{0} \overrightarrow{0} \bar{m}: 0 \\
000 \\
000\end{array}$ & 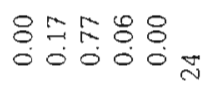 \\
\hline $\begin{array}{l}\hat{\circ} \\
\hat{\theta}\end{array}$ & 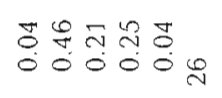 & 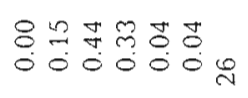 & $\begin{array}{lllll}1 & 1 & 1 & 1 & 1\end{array}$ & 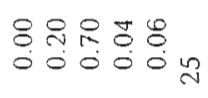 \\
\hline $\begin{array}{l}\mathscr{M} \\
\stackrel{\infty}{\cong}\end{array}$ & 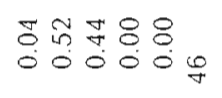 & 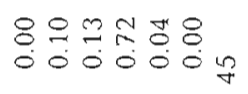 & 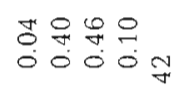 & 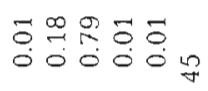 \\
\hline 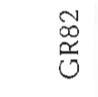 & 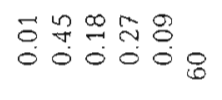 & 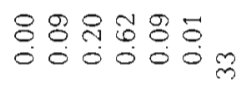 & 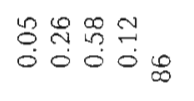 & 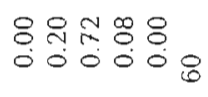 \\
\hline 象 & 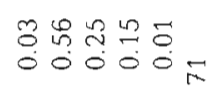 & 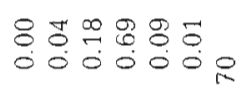 & 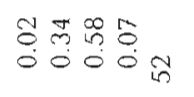 & 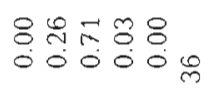 \\
\hline 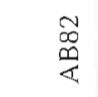 & 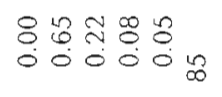 & 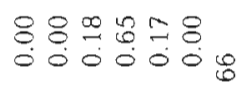 & 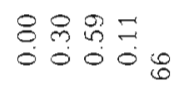 & 듀요요요 \\
\hline $\begin{array}{l}\mathscr{m} \\
\stackrel{\infty}{\simeq} \\
\stackrel{\infty}{\infty}\end{array}$ & 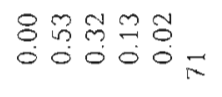 & 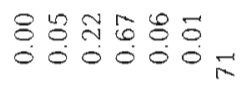 & $\begin{array}{lll}3 \overrightarrow{0} & 0 \\
0 & 0 & 0\end{array}$ & 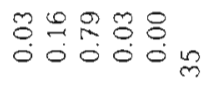 \\
\hline $\begin{array}{l}\widetilde{\infty} \\
\stackrel{\infty}{\infty} \\
\stackrel{\sim}{\infty}\end{array}$ & 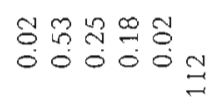 & $\begin{array}{llll}8 \overrightarrow{0} & 0 & 8 \\
0 & 0 & 0 \\
0 & 0 & 0 & 0\end{array}$ & $\begin{array}{l}8000 \\
8000 \\
00000\end{array}$ & 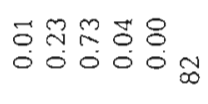 \\
\hline$\stackrel{\dot{\infty}}{\stackrel{\oplus}{\ominus}}$ & $\begin{array}{l}88: \sigma 8 \\
00000 \\
0 \\
0\end{array}$ & 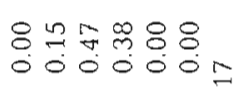 & 11111 & $\begin{array}{l}88: 08: 8 \\
00000 \\
000\end{array}$ \\
\hline$\stackrel{+\infty}{\stackrel{\infty}{P}}$ & 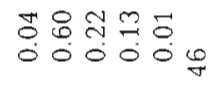 & 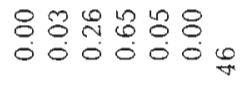 & $\begin{array}{lllll}1 & 1 & 1 & 1 & 1\end{array}$ & 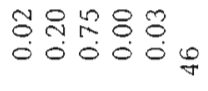 \\
\hline$\stackrel{\infty}{P}$ & 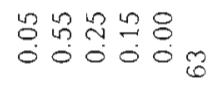 & 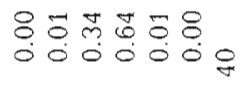 & 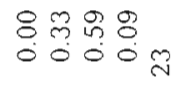 & $\begin{array}{llllll}1 & 1 & 1 & 1 & 1 & 1\end{array}$ \\
\hline 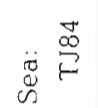 & 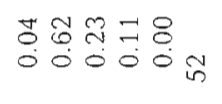 & 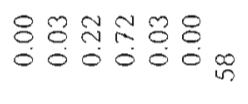 & 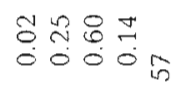 & $\begin{array}{l}8 \pi 058 \\
80000 \\
0000\end{array}$ \\
\hline 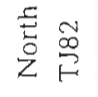 & 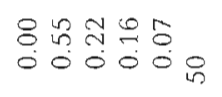 & 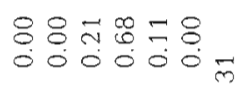 & 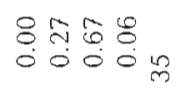 & 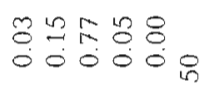 \\
\hline$\frac{\stackrel{Q}{\varrho}}{\bar{\psi}}$ & $\sigma \backsim z$ & $-N m$ ris & $-N m \sigma Z$ & $\sim \sim m \sigma Z$ \\
\hline$\underset{\tilde{U}}{\stackrel{n}{\Xi}}$ & $\overline{\check{z}}$ & 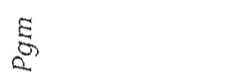 & $\sqrt[2]{3}$ & $T^{2}$ \\
\hline
\end{tabular}


Table 3. Mytilus edulis. Temporal heterogeneity in allelic frequencies as revealed by a genic contingency chi-sciuare test (Workman \& Niswander 1970) in populations from the North Sea caast of Sweden

\begin{tabular}{|llrrl|}
\hline Group & Locus & $x^{2}$ & df & \multicolumn{1}{c|}{$p$} \\
\hline TJ 82/84/85/87 & Pgi & 25.4 & 12 & $<0.025$ \\
& Pgm & 16.1 & 9 & ns \\
& Ap & 13.2 & 8 & ns \\
BR 82/83 & Lap & 6.3 & 6 & $\mathrm{~ns}$ \\
& Pgi & 5.6 & 4 & $\mathrm{~ns}$ \\
& Pgm & 4.8 & 4 & $\mathrm{~ns}$ \\
& Ap & 3.7 & 3 & $\mathrm{~ns}$ \\
AB 82/83 & Lap & 5.4 & 3 & $\mathrm{~ns}$ \\
& Pgi & 13.7 & 4 & $<0.01$ \\
& Pgm & 10.3 & 4 & $<0.05$ \\
& Ap & 4.2 & 3 & $\mathrm{~ns}$ \\
ID 83/87 & Lap & 4.2 & 3 & $\mathrm{~ns}$ \\
& Pgl & 31.4 & 4 & $<0.005$ \\
& Pgm & 25.9 & 4 & $<0.005$ \\
& Ap & 4.9 & 4 & $\mathrm{~ns}$ \\
\hline
\end{tabular}

the native Baltic population (Table 2; Fig. 2a), while at $P g m$ and $A p$, it became different to both the Baltic and the North Sea populations (Figs. 2b,c).

\section{DISCUSSION}

Our results support that of Theisen (1978), Varvio et al. (1988), and Bulnheim \& Gosling (1988) in that large genetic differences are present between Baltic and North Sea populations of Mytilus. The allele frequency distributions of our study are similar to those of earlier studies although, probably due to small sample sizes, we did not reveal as many rare alleles at Pgm and Pgi as earlier reported. The genetic differences between Baltic and North Sea populations may be due to: (1) The Baltic mussels descend from a separate evolutionary lineage which has been reproductively isolated from the North Sea populations for a long time during which the large genetic differences observed have been accumulated through stochastic processes. The recent origin of the Baltic Sea suggests that jf this is the case the evolutionary lineage which includes the Baltic mussels has evolved outside the Baltic. (2) The brackish-water environment of the Baltic favours different alleles at a number of enzyme loci, and despite distinct genotypes today the 2 populations have a common origin.

Varvio et al. (1988) argued that the genetic similarity between Baltic and e.g Canadian 'Group III' mussels indicates that they belong to the same evolutionary lineage, and McDonald \& Koehn (1988) claimed species status for the taxon Mytilus trossulus found in the Baltic, eastern Canada, northern California, Oregon and Alaska. McDonald \& Koehn (1988) gave no salinity ranges of the sampled localities but mentioned that the 'edulis-like' mussels ( $M$. trossulus and $M$. galloprovincialis) of the Pacific coast are common in bays and are also present in the intertidal area of some exposed coast'. In Ireland, M. galloprovincialis prefers exposed sites when co-occurring with $M$. edulis (Skibinski et al. 1983) and thus it seems possible that the bay mussels of McDonald \& Koehn's Pacific sites are $M$. trossulus. Koehn et al. (1984) described the sites of the 'Group III' mussels from eastern Canada (i.e. $M$. trossulus) as 'open coastal sites', in contrast to the 'Group II' mussels (i.e. M. edulis) which inhabited 'more protected or estuarine sites'. However, GartnerKepkay et al. (1983) found that estuarine sites with more fluctuating salinities ('head of bay sites') have generally faster-migrating alleles in the Lap, Pep and Pgm loci compared to sites of more stable salinities in the mouth of estuaries, and that genetic similarities correlated with environmental type rather than with geographical distance between populations. This supports the hypothesis of selective differences between populations of estuarine and oceanic salinities. These findings seem contradictory to what Koehn et al. (1984)

Table 4. Mytilus edulis. Sampless transferred between Baltic (AS) and North Sea (TJ) site. 'Normal' suvival rates are as high as mean survival of rope-growing mussels native to the site - that is, a minor part of the mussels on a rope will normally fall off due to space and food competition. The survival rate of $A S 86^{\circ}$ was initially normal but aftor 12 mo in the North Sea the mortality rate increased dramatically. TJ84 ${ }^{\circ}$ showed a high mortality during the week of acclimation in the laboratory to the salinity of the Baltic site

\begin{tabular}{|cccccc|}
\hline Sample & $\begin{array}{c}\text { Direction } \\
\text { of transfer }\end{array}$ & $\begin{array}{c}\text { No. trans- } \\
\text { ferred }\end{array}$ & $\begin{array}{c}\text { Age of transferred } \\
\text { mussels } \\
\text { (mo) }\end{array}$ & $\begin{array}{c}\text { Time in } \\
\text { new habitat } \\
\text { (mo) }\end{array}$ & $\begin{array}{c}\text { Survival } \\
\text { rate }\end{array}$ \\
\hline AS83. & AS to TJ & ca 10000 & 14 & 1 & normal \\
AS84. & AS to TJ & ca 10000 & 2 & 8 & normal \\
AS85. & AS to TJ & ca 10000 & 12 & 4 & normal \\
AS86. & AS to TJ & ca 40000 & 2 & 24 & $0.5 \%$ \\
TJ84. & TJ to AS & 600 & 4 & 20 & $3 \%$ \\
\hline
\end{tabular}


reported, but their recognition of 'open coast' and 'protected' sites seems to be on a macrogeographic scale as obviously their open coast sites included both the 'head of bay' and 'mouth of bay' sites of Gartner-Kepkay et al. (1983).

Pgi and Pgm, two of the most important loci used by Varvio et al. (1988) and McDonald \& Koehn (1988) to discriminate between $M$. trossulus and $M$. edulis, reveal large variation between Baltic and North Sea populations and to a lesser extent variation also among the North Sea sites of our study (e.g. ID87 at Pgm and ID83 at Pgi). The change in allelic frequencies of the transplanted populations indicate that the extensive differentiation between Baltic and North Sea Mytilus in $P g i$ and $P g m$ may be attributed to selection. Furthermore, as the mussels of the small and polluted estuarine site ID are recruited by tidal currents from open coast populations, it seems likely that the genetic differences between this and nearby North Sea sites are consequences of selective survival of North Sea $M$. edulis genotypes.

The Baltic and North Sea populations differed also at Lap, but at this locus the Mytilus trossulus of eastern Canada were more different to the Baltic mussels than were these to the North Sea mussels (Varvio et al. 1988). At Ap, Baltic and North Sea genotypes are similar, but on the other hand the east and west Atlantic populations of $M$. edulis differ (Varvio et al. 1988). Similarly, Aap differed between Baltic and North American populations (McDonald \& Koehn 1988), but not between Icelandic and Baltic populations (Varvio et al. 1988). At $O d h$, no differences were found between $M$. trossulus and $M$. edulis by McDonald \& Koehn (1988) or by Varvio et al. (1988), although Bulnheim \& Gosling (1988) found differentiation between Baltic and North Sea samples at this and at Est-D. Thus of 8 polymorphic loci, some 5 (Pgi, Pgm, Lap, Est and Mpi) differ between Baltic and North Sea mussels. However, three of these loci $(P g m, P g i$ and Lap) experience selection over salinity gradients (Theisen 1978. Hilbish \& Koehn 1985a,b, this study), while this possibility has not been examined in Mpi and Est. Watt (1985) argues that enzymes which are central to cellular processes are more likely than other enzymes to be under selection. Indeed, at both Lap and Pgi different allozymes have different catalytic efficiency (Koehn \& Siebenaller 1981, Hall 1985).

The taxonomic status of the Baltic mussels is essentially set by the amount of gene flow over the zone of contact, and this is independent of whether the cline is primary or secondary. If, however, a reproductive barrier is present, it seems more likely to have evolved during isolation of 2 allopatrically developing lineages than between 2 ecotypes, in view of the short evolutionary history of the Baltic. Varvio et al. (1988) reported that the Baltic and North Sea populations 'commonly interbreed'. Our study indicates that postsettlement Baltic mussels may survive for rather long periods in the North Sea, and possibly participate in reproduction, although, as shown by Hilbish \& Zimmerman (1988) a difference in allozyme frequencies at one locus ( $L a p$ ) may be enough to displace the timing of the reproduction in 2 genotypes of Mytilus edulis. The polymorphic locus Ap shows almost no differentiation between Baltic and North Sea populations, or between $M$. trossulus and $M$. edulis populations of Canada, while significant differentiation has been established over the Atlantic Ocean (Bulnheim \& Gosling 1988, Varvio et al. 1988). The simplest explanation for the variation in $A p$ is that this locus is selectively neutral over the environments encountered by these Mytilus populations, and this suggests furthermore that there is a gene flow between Baltic and North Sea populations. That alleles of Pgi, Pgm and Lap typical of the Baltic mussels are present, albeit often at low or very low frequencies, in the North Sea, and vice versa supports this suggestion. In fact, no locus is diagnostic between the Baltic and North Sea populations (Bulnheim \& Gosling 1988, Varvio et al. 1988) although McDonald \& Koehn (1988) claim that Mpi has a unique 'trossulus-allele'; this allele is present at low frequencies in European and Canadian populations of $M$. edulis (Varvio et al, 1988).

Despite a certain gene flow, hybrids may, however, be more or less non-viable due to genetic incompatibility at several loci. Hybrid non-viability impedes gene flow, but as shown by Barton \& Bengtsson (1986), for gene flow to be significantly reduced over much of the genome, hybrids must be substantially less fit than non-hybrids, and the number of genes which make the barrier must be so large that most other genes are closely linked to one or another of the loci under selection. Furthermore, even with a strong barrier to neutral genes a gene which is slightly favourable on both sides of the barrier will easily cross the hybrid zone (Barton 1979), and as argued by Barton \& Hewitt (1985) as long as this occurs it is relevant to consider the 2 populations as belonging to the same biological species.

Substantial genetic differentiation may evolve rapidly in traits under selection (Endler 1977, 1986). In the marine snails Littorina saxatilis, for example, sharp genetic gradients are found over distances in the range of metres only (this species lacks a pelagic larva), when the micro-environment changes accordingly (Janson 1982, 1983, Janson \& Ward 1985, Johannesson \& Johannesson 1989), while no or small differentiation occurs in neutral enzyme loci (Janson \& Ward 1984, Johannesson \& Johannesson 1989).

The genetic differences found between Baltic and North Sea Mytilus are according to our study, at least at 
some of the loci, deterministic rather than stochastic and thus not conclusive in a phylogenetic analysis Gene flow, albeit restricted by selection in certain loci is most certainly present between Baltic Mytilus and $M$. edulis of the North Sea, although no one has as yet estimated the amount of gene flow in characters shown to be unaffected by selection. As there is no a priori minimum level of gene flow at which one should consider taxa to be incipient species, the decision will always be arbitrary when to consider 2 taxa as conspecific. The situation is as complex in the case of the partly sympatric taxa $M$. edulis and $M$. galloprovincialis Lmk which hybridize to different degrees around the British Isles (Skibinski et al. 1983). While some authors consider the genetic differences large enough to warrant the discrimination of 2 distinct species (McDonald \& Koehn 1988) others argue that they are to be considered conspecific (Skibinski et al. 1983, Gosling 1984). An immunological tests of the 3 Mytilus taxa, edulis, trossulus and galloprovincialis (Brock 1985), supports the conclusion of 3 conspecific taxa. We argue that allozyme differences, as well as genetic differences in morphological and physiological characters (Kautsky et al. 1990, Tedengren et al. 1990), which may be caused by differential selection in different environments (of micro- and macro-scale) should not be used as indicators of taxonomic ranks. Furthermore, it is premature to reject the possibility of the Baltic mussels being a specialized brackish water ecotype of North Sea $M$. edulis, that is, the 2 taxa originating from the same ecolutionary lineage.

Acknowledgements. We thank Dr K. Koop and 3 anonymous reviewers for valuable comments, the directors of Tjärnö Marine Biological Laboratory and Askö Laboratory for providing laboratury facilities, and the Swedish Natural Science Research Council for support to one of us (K.J.).

\section{LITERATURE CITED}

Barton, N. H. (1979). Gene flow past a cline. Heredity 43: $333-339$

Barton, N., Bengtsson, B. O. (1986). The barrier to genetic exchange between hybridising populations. Heredity 56 $357-376$

Barton, N. H., Hewitt, G. M. (1985). Analysis of hybrid zones Ann. Rev. Ecol. Syst. 16: 113-148

Brock, V. (1985). Immuno-electrophoretic studies of genetic relations between populations of Mytilus edulis and $M$. galloprovincialis from the Mediterreanean, Baltic, east and west Atlantic, and east Pacific. In: Gibbs, P. E. (ed.) Proc. 19th Eur. mar. biol. Symp. Cambridge University Press, Cambridge, p. 515-520

Bulnheim, H.-P., Gosling, E. (1988). Population genetic structure of mussels from the Baltic Sea. Helgoländer Meeresunters. 42: 113-129

Endler, J. A. (1977). Geographic variation, speciation and clines. Princeton University Press, Princeton, New Jersey
Endler, J. A. (1986). Natural selection in the wild. Princeton University Press, Princeton, New Jersey

Fairbairn, D. J., Roff, D. A. (1981). Testing genetic models of isozyme variability without breeding data: can we depend on the $x^{2}$ ? Can. J. Fish. Acruat. Sci. 37: 1149-1159

Fevolden, S. E., Garner, S. P. (1986). Population genetics of Mytilus edulis (L.) from Oslofjorden, in oil-polluted water Sarsia 71: 247-257

Gartner-Kepkay, K. E., Zouros, E., Dickie, L. M., Freeman, K. R. (1983). Genetic differentiation in the face of gene flow: a study of mussel populations from a single Nova Scotia embayment. Can. J. Fish. Aquat. Sci. 40: 443-451

Gosling, E. M. (1984). The systematic status of Mytilus galloprovincialis in Western Europe: a review. Malacologia 25: $551-568$

Hall, J. G. (1985). Temperature-related kinetic differentiaion of glucosephosphate isomerase alleloenzymes isolated from the blue mussel, Mytilus eaulis. Biochem. Genet. 23: $705-728$

Harris, H., Hopkinson, D. A. (1976). Handbook of enzyme electrophoresis in human genetics. North Holland, Amsterdam

Hilbish, T. J., Deaton, L. E., Koehn, R. K. (1982). Effect of an allozyme polymorphism on regulation of cell volume Nature, Lond. 298: 688-689

Hilbish, T J., Koehn, R. K. (1985a). Exclusion of the role of secondary contact in an allele frequency cline in the mussel Mytilus edulis. Evolution 39: 432-443

Hilbish, T J., Koehn, R. K. (1985b). The physiological basis of natural selection at the Lap locus. Evolution 39: 1302-1317

Hilbish, T. J., Zimmerman, K. M. (1988). Genetic and nutritional control of the gametogenic cycle in Mytilus edulis Mar. Biol. 98: 223-228

Hvilsom, M. H., Theisen, B. F. (1984). Inheritance of allozyme variations through crossing experiments with the blue mussel, Mytilus edulis L. Hereditas 101. 1-7

Janson, K. (1982). Genetic and environmental effects on the growth rate of Littorina saxatilis. Mar Biol, 69: 73-78

Janson, K. (1983). Selection and migration in two distinct phenotypes of Littorina saxatilis in Sweden. Oecologia (Berl.) 59: 58-61

Janson, K., Ward, R. D. (1984). Microgeographic variation in allozyme and shell characters in Littorina saxatilis Olivi (Prosobranchia: Littorinidae). Biol. J. linn. Soc. 22: 289-307

Janson, K., Ward, R. D. (1985). The taxonomic status of Littorina tenebrosa Montagu as assessed by morphological and genetic analyses. J. Conch. 32: 9-15

Johannesson, K., Johannesson, B. (1989). Clinal variation in Aat over vertical transects of rocky shores suggests selection in populations of Littorina saxatilis Olivi (Prosobranchia). Genet. Res. 54: 7-11

Kautsky, N., Tedengren, M., Johannesson, K. (1990). Genotypic and phenotypic differences between Baltic and North Sea populations of Mytilus edulis evaluated through reciprocal transplantations. I. Growth and morphology. Mar Ecol. Prog. Ser. 59: 203-210

Koehn, R. K. (1978). Physiology and biochemistry of enzyme variation: the interface of ecology and population genetics. In: Brussard, P. F. (ed.) The interface of ecology and genetics. Springer Verlag, Berlin, p. 51-72

Koehn, R. K., Hall, J. G., Innes, D. J. Zera, A. J. (1984). Genetic differentiation of Mytilus edulis in eastern North America. Mar. Biol. 79: 117-126

Koehn, R. K., Milkman, R., Mitton, J. B. (1976). Population genetics of marine polecypods. IV. Selection, migration and genetic differentiation in the blue mussel Mytlus edulis. Evolution 30: 2-32 
Koehn, R. K., Newell, R. I. E., Immerman, F. (1980). Maintenance of an aminopeptidase allele frequency cline by natural selection. Proc. natn. Acad. Sci. USA. 77: $5385-5389$

Koehn, R. K., Siebenaller, J. F. (1981). Biochemical studies of amino-peptidase polymorphism in Mytilus edulis. II. Dependence of reaction rate on physical factors and enzyme concentration. Biochem. Genet. 19: 1143-1162

McDonald, J. H., Koehn, R. K. (1988). The mussels Mytilus galloprovincialis and $M$. trossulus on the Pacific coast of North America. Mar. Biol. 99: 111-118

Nei, M. (1972). Genetic distances between populations. Am Nat. 106: 283-292

Norman, E. (1977). The geographical distribution and the growth of the wood-boring molluscs Teredo navalis L., Psiloteredo megotara (Hanely) and Xylophaga dorsalis (Turton) on the Swedish west coast. Ophelia 16: 233-250

Romare, P., Håkansson, M., Rosenberg, R. (1982). Fastsättning och efterföljande spridning av blåmusslan Mytilus edulis L. vid svenska västkusten. Meddelande frăn Havsfiskelaboratoriet Lysekil 285: 1-16 (In Swedish)

This article was submitted to the editor
Shaw, C. R., Prasad, R. (1970). Starch gel electrophoresis of enzymes - a compilation of recipes. Biochem. Genet. 4 : $297-320$

Skibinski, D. O. F., Beardmore, J. A., Cross, T. F. (1983). Aspects of the population genetics of Mytilus (Mytilidae; mollusca) in the British Isles. Biol. J. Linn. Soc. 19: 137-183

Tedengren, M., André, C., Johannesson, K., Kautsky, N. (1990). Genotypic and phenotypic differences between Baltic and North Sea populations of Mytilus edulis evaluated through reciprocal transplantations. III. Physiology. Mar. Ecol. Prog. Ser. 59: 221-227

Theisen, B. F. (1978). Allozyme clines and evidence of strong selection in three loci in Mytilus edulis L. (Bivalvia) from Danish waters. Ophelia 17: 135-142

Varvio, S.-L., Koehn, R. K.. Väinölä, R. (1988). Evolutionary genetics of the Mytilus edulis complex in the North Atlantic region. Mar. Biol. 98: 51-60

Watt, W B. (1985). Bioenergetics and evolutionary genetics opportunities for new synthesis. Am. Nat. 125: 118-143

Workman, P. L., Niswander, J. D. (1970). Population studies on southwestern Indian tribes. II. Local genetic differentiation in the Papago. Am. J. hum. Genet. 22: 24-49

Manuscript first received: April 14, 1989

Revised version accepted: September 28, 1989 